\title{
LIQUEFACTION OF COALS USING ULTRA-FINE PARTICLE, UNSUPPORTED CATALYSTS: IN SITU GENERATION BY RAPID EXPANSION OF SUPERCRITICAL FLUID SOLUTIONS
}

\author{
QUARTERLY TECHNICAI PROGRESS REPORT \\ for the period
}

October 1, 1991 through December 31, 1991

\author{
Date Prepared \\ January 1992
}

Prepared by

TEXTRON DEFENSE SYSTEMS

2385 Revere Beach Parkway

Everett, Massachusetts 02149

$$
\text { Prepared for }
$$

U.S. DEPARTMENT OF ENERGY

Pittsburgh Energy Technology Center

Pittsburgh, Pennsylvania 15236-0940

Under Contract No.: DE-AC22-90PC90053

\section{MASTER}

DISTRIBUTION OF THIS DOCUMENT IS UNLIMITED 
TABLE OF CONTENTS

Page

1.0 SUMMARY

2.0 TECHNICAI PROGRESS

2.0 FUTURE WORK

\section{DISCLAIMER}

This report was prepared as an account of work sponsored by an agency of the United States Government. Neither the United States Government nor any agency thereof, nor any of their employees, makes any warranty, express or implied, or assumes any legal liability or responsibility for the accuracy, completeness, or usefulness of any information, apparatus, product, or process disclosed, or represents that its use would not infringe privately owned rights. Reference herein to any specific commercial product, process, or service by trade name, trademark, manufacturer, or otherwise does not necessarily constitute or impli/ its endorsement, recommendation, or favoring by the United States Government or any agency thereof. The views and opinions of authors expressed herein do not necessarily state or reflect those of the United States Government or any agency thereof. 


\subsection{SUMMARY}

This is the fifth Quarterly Report for this program. It covers the period October 1, 1991 through December 31, 1991. The purpose of this program is to design and fabricate an experimental ultra-fine particle generation system; use this system to generate ultra-fine, iron compound, catalyst particles; and to access the ability of these ultra-fine catalyst particles to improve the performance of the solubilization stage of twostage, catalytic-catalytic liquefaction processes. The effort applied to this program during this reporting period was focused mainly on bringing Quarterly Reporting back in lins with the original milestone schedule. At this point in time we are current with all reporting requirements. Regarding technical progress, some effort was applied to experimental test matrix refinement.

Experimental test matrix definition is part of Task 2 "Experiment Design and Fabrication." Based on recent results presented by Dean Matson at the 1991 Pittsburgh Coal Conference and program budget constraints, it is possible and necessary to construct a test matrix with better focus and scope. The original test matrix contained well over 32 elements, which would have required extensive test rig operation and costly catalyst characterization analyses. The original test matrix included two (2) supercritical solvents $\left(\mathrm{CO}_{2}\right.$ and $\left.\mathrm{H}_{2} \mathrm{O}\right)$, two (2) catalyst precursors (two of the following: $\mathrm{Fe}(\mathrm{CO})_{5}, \mathrm{FeS}_{2}$, or $\mathrm{Fe}_{2} \mathrm{O}_{3}$ ), two 
(2) solubilizing or coprecipitant additives $\left(\mathrm{CS}_{2}\right.$ and $\left.\mathrm{H}_{2} \mathrm{~S}\right)$, two

(2) sets of pre-expansion temperature and pressure conditions for each supercritical solution, and variations on solute, solvent, and additive concentrations.

Matson found that both $\mathrm{FeS}_{2}$ and $\mathrm{Fe}_{2} \mathrm{O}_{3}$ have negligible solubilities in supercritical water. Also we have concluded that safety and environmental regulations will make testing using $\mathrm{CS}_{2}$ and $\mathrm{H}_{2} \mathrm{~S}$ as supercritical solvents for $\mathrm{FeS}_{2}$ and $\mathrm{Fe}_{2} \mathrm{O}_{3}$ too costly to be undertaken. Based on these factors, particle generation studies based on $\mathrm{FeS}_{2}$ and $\mathrm{Fe}_{2} \mathrm{O}_{3}$ will be given low priority and will be undertaken as program resources allow. The main thrust will be to explore particle generation involving the catalyst precursor $\mathrm{Fe}(\mathrm{CO})_{5}$ and the supercritical solvent $\mathrm{CO}_{2}$. Although $\mathrm{Fe}(\mathrm{CO})_{5}$ is known to be an effective catalyst precursor for hydroliquefaction of coal, it is apparent that the final form, thus active catalyst, is pyrrhotite. Thus, in order to produce catalyst particles with high activity, a sulfur compound must be introduced during the particle generation process. Gas/liquid phase chemical equilibrium calculations at 1 atm indicate that a mixture of $998 \mathrm{CO}_{2}, 18 \mathrm{Fe}(\mathrm{CO})_{5}$, and $18 \mathrm{CS}_{2}$ (molar basis) produces $\mathrm{FeS}_{2}$ from $300-600 \mathrm{~K}$ and $\mathrm{FeS}$ above $600 \mathrm{~K}$. Although the kinetic rates are not known, especially under supercritical conditions, these results suggest that it may be possible to produce highly active, ultra-fine, iron sulfide catalyst particles using supercritical $\mathrm{CO}_{2}$. The preliminary refined test matrix includes studies that will explore the effect of introducing the additive 
$\mathrm{CS}_{2}$.

If the chemistry just described does not take place, particles will be generated consisting of coprecipitated metallic iron and $\mathrm{CS}_{2}$. Under the severe conditions of the sulubilization stages of liquefaction processes, these coprecipitants will probably react to form activated pyrrhotite. In either case, suitable catalyst particles are obtained. As test rig assembly continues, the test matrix will be further refined. We anticipate completing test rig assembly by the end of the first quarter of 1992 . 


\subsection{TECHNICAL PROGRESS}

This program consists of five tasks that cover technical effort and management details. These tasks are listed below and their status is discussed in the remainder of this section.

Task 1 Project Work Plan

Task 2 Experiment Design and Fabrication

Task 3 Solute/Solvent Optimization

Task 4 Catalyst Preparation and Evaluation

Task 5 Reporting and Documentation

\section{Task 1: Project Work Plan}

This is a completed task and the work plan report was submitted during November 1990.

\section{Task 2: Experiment Design and Fabrication}

During the first twelve months of this program test rig design was undertaken/completed, safety/environmental support systems were designed/installed, and system assembly commenced. Due to the unexpected costs incurred because of the special alloys required to prevent corrosion of the high temperature/pressures elements of the system under supercritical water conditions, support systems required to meet safety/environmental regulations, and delays due to procured material lead times, key personnel for this program were shifted to other on-going programs at TDS to minimize program costs. As 
these other programs encountered critical phases, coupled with the effects of a recessionary period on available personnel, retrieving this program's key personnel has been difficult. As a result, no effort was applied to system assembly during the fifth quarter of this program (October - December 1991). Given these circumstances and that quarterly reporting had fallen behind, the fifth quarter of this program was devoted to bringing reporting back in line with the original milestone schedule, with minimal effort applied to technical tasks.

The technical effort applied during the fifth quarter, however, began the process of refining the test ratrix for Tasks 2 and 3 , which are Solute/Solvent Optimization and Catalyst Preparation and Evaluation, respectively. The original solute/solvent optimization test matrix involved two (2) catalyst precursors (two of the following: $\mathrm{Fe}(\mathrm{CO})_{5}, \mathrm{FeS}_{2}$, and $\mathrm{Fe}_{2} \mathrm{O}_{3}$ ), two (2) solubilizing or coprecipitant additives (possibly $\mathrm{H}_{2} \mathrm{~S}$ and $\left.\mathrm{CS}_{2}\right)$, two (2) supercritical solvents $\left(\mathrm{CO}_{2}\right.$ and $\left.\mathrm{H}_{2} \mathrm{O}\right)$, and two (2) sets of pre-expansion temperatures and pressures for each supercritical solution. This yields a test matrix with over 32 elements when solute and/or additive concentration variations are allowed. This is a large optimization test matrix which will lead to excessive test rig operation and costly catalyst characterization analyses. Based on program resource constraints and results presented at the 1991 Pittsburgh Coal Conference, the test matrix given in the Project Work Plan must/can be revised. The results presented at the 1991 Pittsburgh Coal Conference 
by Dean Matson of Battelle Northwest Laboratories indicate that iron pyrite has negligible solubility in supercritical water. In private discussions with Dean Matson it was learned that hematite also has negligible solubility in supercritical water. Based on environmental and safety constraints, it will not be possible to use $\mathrm{CS}_{2}$ or $\mathrm{H}_{2} \mathrm{~S}$ as supercritical solvents. Given these considerations, a preliminary test matrix update has been constructed, which is presented in Table 1. Ultra-fine catalyst generation studies involving pyrite and hematite have been assigned a low priority based on Matson's results, and will be conducted only if program resources permit. The primary focus of ultra-fine catalyst generation studies will involve the catalyst precursor iron pentacarbonyl. Since iron pentacarbonyl [ $\mathrm{Fe}(\mathrm{CO})_{5}$ ] has a relatively low decomposition temperature at ambient pressure, we expect iron pentacarbonyl to reduce to metallic iron under supercritical $\mathrm{CO}_{2}$ conditions. It was implied during discussions with Dean Matson that he has observed this phenomena. This is encouraging because it suggests that we can expect to generate ultra-fine iron particles using iron pentacarbonyl.

Although iron pentacarbonyl exhibits exceptional catalytic activity for the hydroliquefaction of coal, it is apparent that the final form, thus active catalyst, is pyrrhotite. In order to produce catalyst particles with high activity, a sulfur compound should be introduced during the particle generation process. 
Table 1. Updated T'est Matrix.

\begin{tabular}{|c|c|c|c|}
\hline Priority & Primary & optional & Optional \\
\hline solute & $\mathrm{Fe}(\mathrm{CO})_{5}$ & $\mathrm{FeS}_{2}$ & $\mathrm{Fe}_{2} \mathrm{O}_{3}$ \\
\hline $\begin{array}{l}\text { Supercritical } \\
\text { solvent }\end{array}$ & $\mathrm{CO}_{2}$ & $\mathrm{H}_{2} \mathrm{O}$ & $\mathrm{H}_{2} \mathrm{O}$ \\
\hline $\begin{array}{l}\text { Solubilizing or } \\
\text { Coprecipitant Additive }\end{array}$ & $\mathrm{CS}_{2}$ & $\mathrm{CS}_{2}$ or $\mathrm{H}_{2} \mathrm{~S}$ & $\mathrm{CS}_{2}$ or $\mathrm{H}_{2} \mathrm{~S}$ \\
\hline $\begin{array}{l}\text { Supercritical } \\
\text { Fluid Mixture }\end{array}$ & $\mathrm{Fe}(\mathrm{CO})_{5} / \mathrm{Cs}_{2} / \mathrm{CO}_{2}$ & $\begin{array}{l}\mathrm{FeS}_{2} / \mathrm{CS}_{2} / \mathrm{H}_{2} \mathrm{O} \\
\mathrm{FeS}_{2} / \mathrm{H}_{2} \mathrm{~S} / \mathrm{H}_{2} \mathrm{O}\end{array}$ & $\begin{array}{l}\mathrm{Fe}_{2} \mathrm{O}_{3} / \mathrm{CS}_{2} / \mathrm{H}_{2} \mathrm{O} \\
\mathrm{Fe}_{2} \mathrm{O}_{3} / \mathrm{H}_{2} \mathrm{~S} / \mathrm{H}_{2} \mathrm{O}\end{array}$ \\
\hline $\begin{array}{l}\text { Solute/Additive } \\
\text { Concentration (ppm) }\end{array}$ & $\begin{array}{l}\mathrm{Fe}(\mathrm{CO})_{5} / \mathrm{Cs}_{2} \\
50-5 \mathrm{OK} / 0-5 \mathrm{KK}\end{array}$ & $\begin{array}{l}\mathrm{CS}_{2} \text { or } \mathrm{H}_{2} \mathrm{~S} \\
0-5 \mathrm{OK}\end{array}$ & $\begin{array}{l}\mathrm{CS}_{2} \text { or } \mathrm{H}_{2} \mathrm{~S} \\
0-5 \mathrm{OK}\end{array}$ \\
\hline $\begin{array}{l}\text { Pre-Expansion } \\
\text { Pressure (atm) }\end{array}$ & $200-350$ & $<600$ & $<600$ \\
\hline $\begin{array}{l}\text { Pre-Expansion } \\
\text { Temperature (C) }\end{array}$ & $50-100$ & $<600$ & $<600$ \\
\hline
\end{tabular}


Gas/liquid phase chemical equilibrium calculations at 1 atm indicate that a mixture of $998 \mathrm{CO}_{2}, 18 \mathrm{Fe}(\mathrm{CO})_{5}$, and $18 \mathrm{CS}_{2}$ (molar basis) produces $\mathrm{FeS}_{2}$ from $300-600 \mathrm{~K}$ and $\mathrm{FeS}$ above $600 \mathrm{~K}$. Although the kinetic rates are unknown, these results suggest that it may be possible to produce highly active, ultra-fine, iron sulfide catalyst particles using supercritical $\mathrm{CO}_{2}$. If this chemistry does not take place, particles will probably be generated consisting of coprecipitated iron particles and $\mathrm{CS}_{2}$. Under the severe conditions of the solubilization stages of liquefaction processes, these coprecipitants will probably react to form activated pyrrhotite. In either case, a suitable catalyst is obtained.

As test rig assembly continues, the test matrix for Task 2 "Solute/Solvent Optimization" will be further refined. During this time a rough test matrix for Task 4 "Catalyst Preparation and Evaluation" will be defined also.

Task 3: Solute/Solvent Optimization

No effort has been applied to this task yet.

Task 4: Catalyst Preparation and Evaluation

No effort has been applied to this task yet.

\section{Task 5: Reporting and Documentation}

All monthly and quarterly reports have been submitted. 
( )

\subsection{FUTURE WORK}

The scope of the work that will be performed in the next quarter is listed below.

* Resume assembly of test rig. Complete by the beginning of the second quarter of 1992 .

* Continue refining experimental test matrices. 

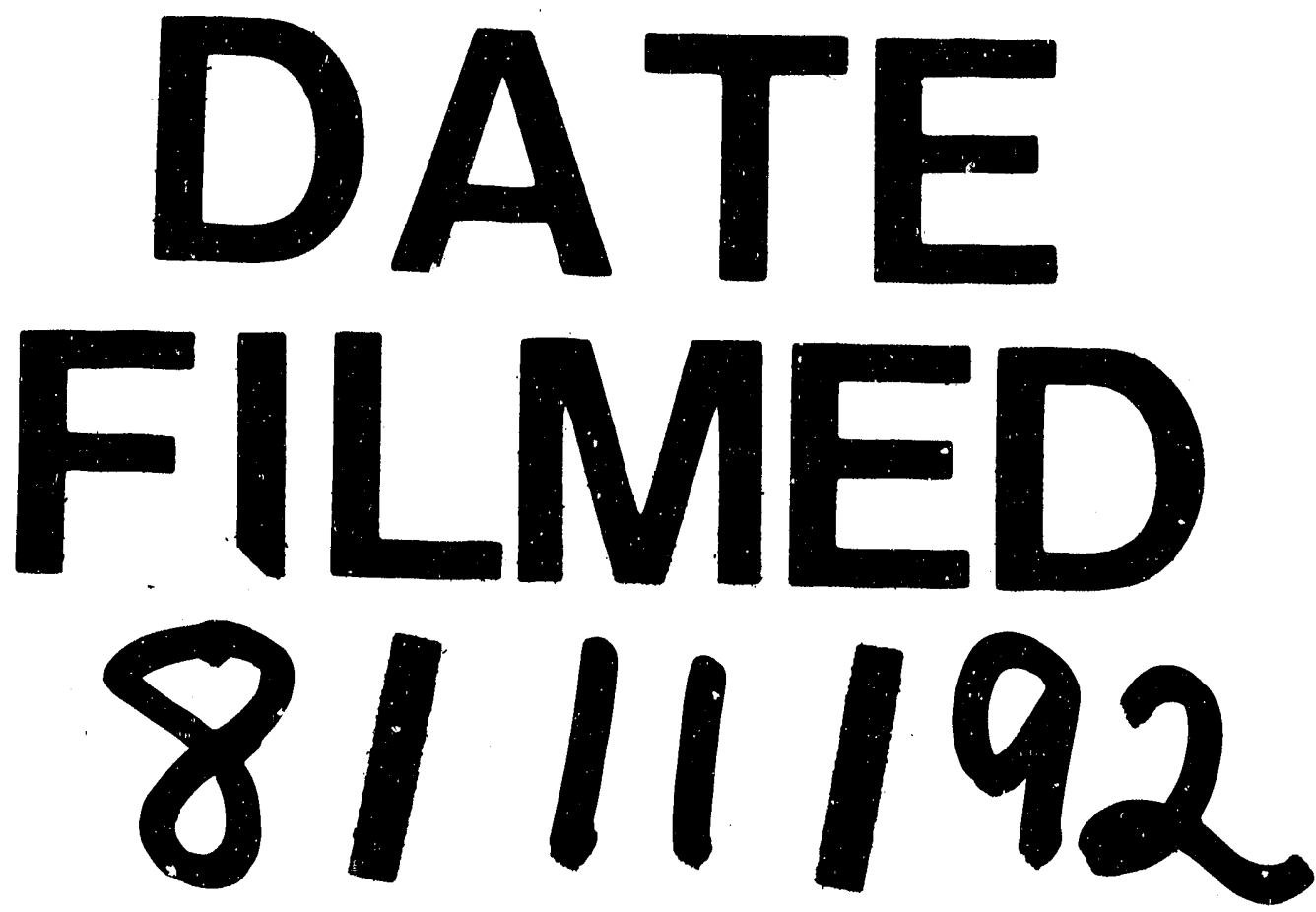